\title{
CRENÇAS DE PROFESSORES E ALUNOS A RESPEITO DA NATUREZA DA CIÊNCIA: RE- SULTADO EMPÍRICO OBTIDO EM UMA INSTITUIÇÃO FEDERAL DE ENSINO
}

\author{
Daniel Fernandes Mendes da Silva \\ Mestre em Ensino de Ciências e Matemática pelo CEFET-RJ \\ Rio de Janeiro, RJ, Brasil \\ fisicodaniel@hotmail.com
}

\section{RESUMO}

O presente artigo tem como propósito demonstrar argumentos favoráveis à inserção do ensino da natureza da ciência (enfoque CTS) no ensino médio para uma formação cientifica e tecnológica adequada, e utilizando como argumento empírico o resultado obtido numa pesquisa aplicada numa Instituição Federal de Ensino. Tal resultado demonstra que para tal inserção é necessário que haja, antes, uma mudança na concepção dos professores a respeito de tal tema.

Palavra-Chave: Natureza da Ciência, CTS e Ensino.

\section{BELIEFS OF TEACHERS AND STUDENTS ABOUT THE NATURE OF SCIENCE: EMPIRICAL RESULTS OBTAINED IN A FEDERAL EDUCATION}

\begin{abstract}
This article aims to demonstrate arguments for the inclusion of teaching the nature of science (CTS approach) in high school for a suitable scientific and technological training, and using empirical argument as the result obtained in applied research in a Federal Institution of Education. This result demonstrates that such inclusion is necessary to have rather a change in the conception of teachers regarding such theme.
\end{abstract}


KeyWords: Nature of Science, CTS e Education.

\section{Introduction}

In the society in which we live, where every day a new technology or scientific discovery is disseminated by the mass media, people must have mastery over some essential scientific elements, or at least know them, to a critical position on issues related to Science and technology. Citizens' participation in decision-making often translates into avoiding the hasty application of innovations that are unaware of the mediumand long-term consequences. In this sense, the importance of the school grows every day, because it acts directly with a significant portion of the population. Given that this portion studies science (Physics, Chemistry and Biology) for at least 4 years, it is necessary to give science education a new dimension, promoting an update and integrating science with the life of each student.

So as to accomplish this proposal, the National Curricular Parameters for Secondary Education suggest that the learning of the Natural Sciences and their Technologies seek the interdisciplinarity and the contextualization of the contents, having as one of the objectives to promote skills and abilities that make the student capable of interventions and Practical judgments. However, in practice this does not happen, since science education in Brazil is done in a fragmented way and its disciplines, in most cases, do not communicate and are focused only on the theoretical foundation of future contents, omitting all the development carried out in the Century and dealing with content in an encyclopedic and formal way (PCNs, 1999).

In science didactics, there is a growing consensus that one of the most important objectives in science teaching in Elementary and Middle School is the better understanding of the nature of science (Matthews, 1998b; McComas, Clough and Almazroa, 1998 apud Acevedo Al., 2005).

Acevedo at al (2008) defines the concept of the nature of science as being 
A variety of aspects about what is science, its internal and external functioning, how it builds and develops the knowledge it produces, the methods it uses to validate that knowledge, the values involved in scientific activities, the nature of the scientific community, the links With technology, society's relations with the technoscientific system and vice versa, the latter's contributions to the culture and progress of society.

The nature of science is an essential element for the scientific and technological literacy of all people, and its insertion in the science curriculum is fundamental to the scientific education of the present (Acevedo, Vázquez and Manassero, 2002, Matthews, 1998a, Ziman, 2000 Apud Acevedo at al, 2008).

This way, the insertion of the nature of science into curricula makes scientific education more appropriate for the 21st century (Acevedo et al., 2005). However, since the nineteenth century, the teaching of science has always been considered the most conflicting, according to Tedesco (2006). In the nineteenth century, there were two major objections to the teaching of science: Firstly, science was seen as an applied science which did not strengthen students' reasoning abilities and their moral development; Secondly, science was associated to a hostile manner to religion, subverting therefore the social order.

At the end of the nineteenth century, an international consensus was generated on the importance of these subjects, and the opposition to science began to weaken. This consensus stems from comparisons of economic and military incomes that some countries, such as Belgium, England, Germany, and others have done, have noted that their deficits were associated with educational and scientific development, causing some educational reforms to modernize their content and expand education. These reforms have always been associated with periods of military defeat and major economic crises.

According to Tedesco (2006), the result of these historical processes is that, nowadays, the sciences are incorporated in the curricula of Elementary and Middle School, but, unlike the official discourse, this incorporation does not bring a scientific formation capable of an understanding of the phenomena that affects the population's 
life.

The introduction of science teaching into the formal curriculum was justified by the need to strengthen rationality and experimental focus, as opposed to dogma and prejudice, but "... The sciences taught eventually became a new theoretical body so much to Plato's taste. The abstract of mathematics taught has been no less accessible than the axiom of physics that is taught in classrooms. Even the modern sciences of nature have found their places of school abstraction in biochemistry or in the description of cellular processes. The realm of the undisputed, the isolated from the social, is science in classrooms, it is certainly far away from the living science in social reality. (Gordillo and González Galbarete, 2002:23 apud Tedesco, 2006)

Another important goal in learning the nature of sciences is to become aware of the interactions between science, technology and society (HTS) (Hodson, 1994 apud Acevedo at al, 2005). The CTS movement aims to ask about the social nature of technological-scientific knowledge and its implications in the different economic, social, environmental and cultural spheres of western societies. Within regards to it, there is a consensus among some authors (Aikenhead, 1994 apud Acevedo at al, 2008) in stating that society maintains a social contract with science and technology, that is: society economically finances science and technology and this, in turns, offers improvements in quality of life, through some benefits, and contribute to economic and social progress and development (Acevedo et al., 2008).

The birth of the CTS movement emerged, after some more critical and cautious attitudes to the advances of Science and Technology (S \& T), between the late 1950s and early 1960s, with the contraction of belief in the neutrality of science and some naive vision of technological development in the face of the irrational advance of modern society. And it had and still has as vision, a more critical formation of future professionals, as well as obtaining new theories about the implications and relations of Sciences and Technologies (Amaral et al, 2011).

Some authors (Acevedo Díaz et al, 2002; Acevedo Díaz, 1998, 2002a, 2002b, 2002c, 2003; Angotti et al, 2001; Barros Filho et al 2010; Bazzo, 2002; Calatayud, 2003; Colombo \& Bazzo, 2002; Iglesia, 1997; Osorio M., 2002a, 2002b; Rezaei \& Katz, 1998; Sebastián, 2000; Silva, C. A. D., 1999 et al; Veraszto et al 2009c; Vilches \& Furió, 1999. 
apud Amaral et al 2011) argue that technological knowledge, in addition to having a fundamental importance so that every citizen can follow closely the transformations that occur daily in our society, students can also be provided with a training capable of assisting in the most different decision-making processes which occur in daily life, taking as reference the values considered as ethical and moral by society (ibid).

The idea of bringing the debate about CTS relations to the classroom has been disseminated through the PCNs as a form of Technological Education, which would be aimed at understanding the origin and use of artifacts, rather than their manufacture (Bazzo, Silveira and Pinheiro, 2007). Linking the CTS relationship in science education is to promote the compression of science and technology, which becomes a continuous presence in our daily lives. For this reason, LDB emphasizes, in article 36, that the Secondary School "[...] will emphasize technological education, an understanding of the meaning of science, of letters and of the arts; Historical process of changes in society and culture; The Portuguese language as an instrument of communication, access to knowledge and exercise of citizenship. " This article states that the learner, in addition to having access to knowledge related to science and technology, must understand how these processes are formed, what consequences and what kind of attitude should be directed to the issue (Bazzo, Silveira and Pinhero, 2007) .

The CTS approach in the curricula serves as an initial awakening in the student, so that he could assume a questioning and critical posture in the near future (Bazzo, Silveira and Pinheiro, 2007).

Based on work produced in 2005 (Werthein and Cunha, 2005 apud Tedesco, 2006), Crodowaldo Pavan, one of the honorary presidents of the Brazilian Society for the Advance of Science and one of the authors of the paper, expresses his concern with Brazil saying that "according to recent statistics released by the media, our country occupies one of the last places in science education in the world, that is, the knowledge produced by leading research groups is not being taken advantage of by our educational project. In this gloomy view, the general picture indicates that, on the whole, the technological backwardness of Brazil has been deepened in the face of the situation of developed countries "(Tedesco, 2006, p.22)

The teaching of science should be conducted in such a way as to stimulate stu- 
dent participation and social responsibility. Scientific literacy is fundamental because it generates understanding of the scientific enterprise and its interactions with technology and society, causing a better exercise of democracy and citizenship. Only then will the students feel that they are holders of meaningful knowledge.

From an educational point of view, Acevedo (Driver et al., 1996 apud 2008, p. 2) states that "democratic argument is a substantial element in favor of including the nature of science in a scientific and technological education of all people, because according to experts, the participation of citizens in technoscientific decisions of social interest requires the understanding of elements of the nature of science.

In order to verify empirically the conception that students and teachers have about the nature of science and technology in the state of Rio de Janeiro, a set of questions has been applied in the Questionnaire on Opinions on Science, Technology and Society (QOCTS - PIEARCTS), using a new quantitative methodology to describe and identify the beliefs of students and teachers.

Forato, Pietrocola and Martins (2011, Gil-Perez et al., 2001) argue that "teachers' views on scientific work lead to their educational practice, implicitly or explicitly reflecting their conceptions about NDC."

This questionnaire was applied to students from the 3rd year of secondary education, students from the first and last period of University (Exact and Human Sciences) and for teachers from the Celso Suckow da Fonseca Federal Center of Technological Education (CEFET) in the state of Rio de Janeiro, In the Maracanã unit between 2007 and 2009. The sample of students and teachers related to the area of exact sciences is shown in Chart 1 below. 


\section{Chat 1}

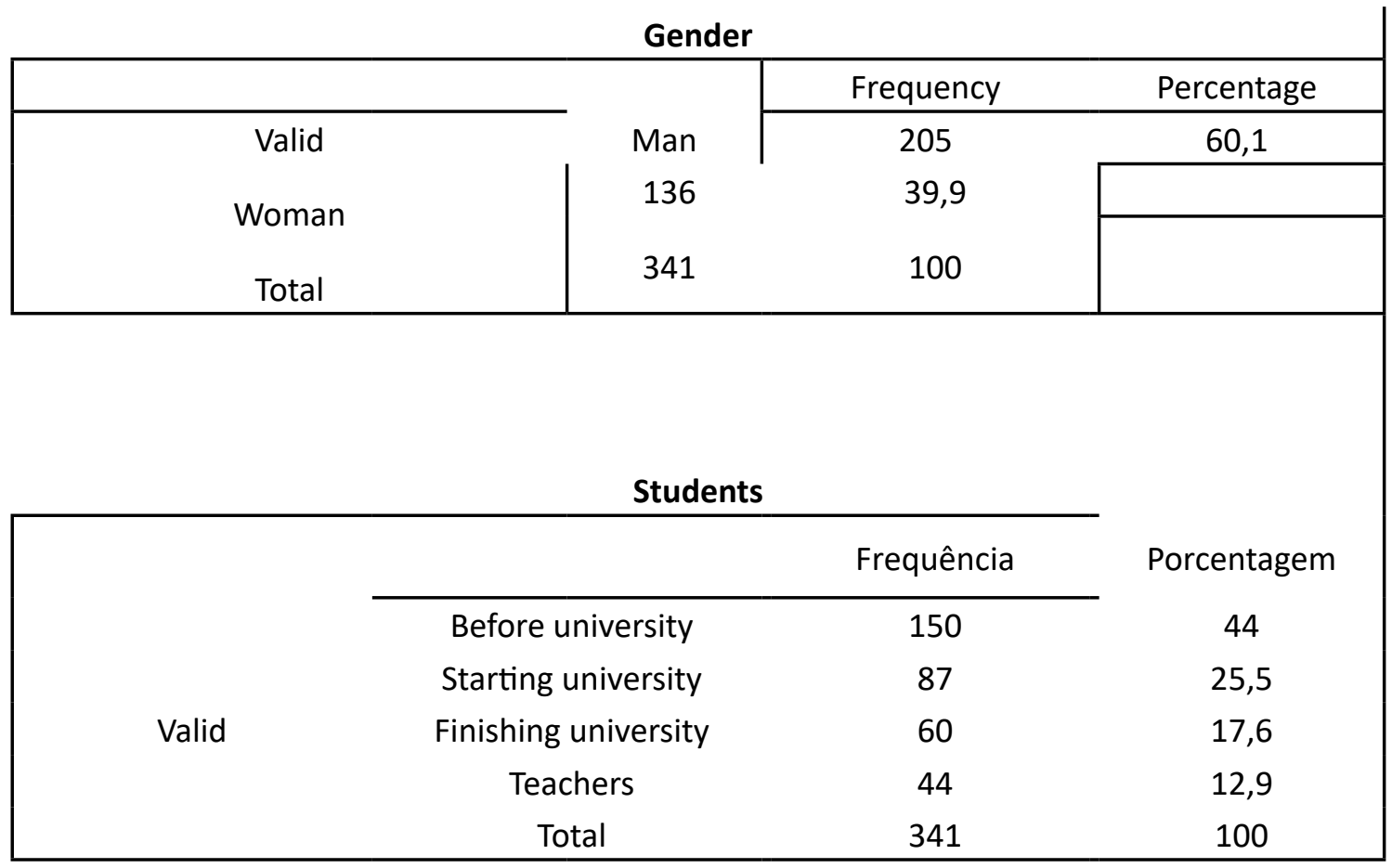

\section{METHODOLOGY}

The methodology used to arrive at a possible agreement on the nature of science (hereafter NOC) is based on collecting the assessments of a panel of 16 expert judges for a direct survey of NOC issues. The judges are composed of 11 men and 5 women, among whom there are teacher trainers (5), philosophers (4), researchers in science didactics (4) and science teachers (3). The majority (12) has a research activity recognized in the scope of the didactics of the sciences or in the education in Science-Technology-Society (from now on CTS) (Acevedo at al., 2008).

The instrument used is the QOCTS-PIEARCTS, composed of 30 multiple choice questions, in which different issues are approached that allow us to knowing the beliefs 
and attitudes about the NOC from a broad CTS perspective that encompasses several thematic perspectives. All questions begin with a text of few lines in which a problem is exposed, followed by a list of phrases that offer different answers referring to the problem exposed (Acevedo at al., 2008).

The judges evaluated the adequacy of each of the QOCTS-PIEARCTS phrases in the context of each question and the perspective of knowledge of philosophy, history, and sociology of science using a nine-point scale (1-9) whose scores have significance in Graph 2. The score of the questions, attributed by the judges, correspond to different degrees according to the naive sentences (I) in the scale of 1 to 3 ; In the same way that the scores between 4 and 6 indicate plausible sentences (P); And the scores between 7 and 9, appropriate phrases (A) (Acevedo, Acevedo, Manassero and Vázquez, 2001; Manassero, Vázquez and Acevedo, 2001; Vázquez, Acevedo and Manassero, 2000 apud Acevedo, 2008).

Chart 2 - Scale of evaluation of each QOCTS-PIEARCTS phrase with the interpretation of its meaning.

\begin{tabular}{|c|c|c|c|c|c|c|c|c|}
\hline \multicolumn{4}{|c|}{$\leftarrow$ MENOS ADEQUADAS } & & \multicolumn{4}{|c|}{ MAIS ADEQUADAS $\rightarrow$} \\
\hline \multicolumn{3}{|c|}{ Ingênuas, inadequadas } & \multicolumn{3}{|c|}{ Plausiveis, parciaimente aceitáveis } & \multicolumn{3}{|c|}{ Adequadas, apropriadas } \\
\hline $\begin{array}{l}\text { Totalmente } \\
\text { ingènuas }\end{array}$ & $\begin{array}{c}\text { Muito } \\
\text { ingênuas }\end{array}$ & Ingênuas & $\begin{array}{c}\text { Pouco } \\
\text { plausiveis }\end{array}$ & Plausiveis & $\begin{array}{c}\text { Muito } \\
\text { plausiveis }\end{array}$ & Adequadas & $\begin{array}{c}\text { Muito } \\
\text { adequadas }\end{array}$ & $\begin{array}{l}\text { Totaimente } \\
\text { adequadas }\end{array}$ \\
\hline 1 & 2 & 3 & 4 & 5 & 6 & 7 & 8 & 9 \\
\hline
\end{tabular}

Participants should score each sentence (1 = "I do not agree" / 9 = "I fully agree"), according to the degree of agreement, and two options for not punctuating ("I do not understand" and "I do not know"). This evaluation format allows participants to express their views on all the sentences of the question. Subsequently, the values become an attitudinal index, with values ranging from -1 to +1 , taking into account the classification of each sentence (Naive, Plausible or Adequate), which classification was assigned by the judges. These indexes are the quantitative indicators of participants' beliefs and approaches, and measure the degree of attunement of the direct score, marked by the participants, with the category classified by the judges. The closer the participant gets to the judges' ranking, the higher the index $(+1)$, and with this the participant's belief will be considered adequate; (Manassero et al., 2001), and, in the case of Manassero et al. 
(2001), in which the participant scores more than the judge's rank, the more naive his belief is considered, 2010).

\section{RESULTS}

Among several issues and issues related to QOCTS-PIEARCTS, this article will analyze the results obtained in question 20511, which has as its theme the Influence of Society in Science and Technology - an issue that is related to Educational Institutions -, focusing only on the beliefs that students and teachers linked to the area of exact sciences possess.

20511 The success of science and technology in our country depends on having good scientists, engineers and technicians. Therefore, the country needs students to study more sciences in school.

\section{It is necessary for students to study more sciences:}

A. because it is important to help our country keep the level of others.

B. because science affects almost every aspect of society. As in the past, the future depends on good scientists and technologists.

C. Encourage (encourage) students to study more sciences, but a different kind of science course. They must learn how science and technology affect their daily lives.

\section{Students DO NOT need to study more sciences:}

D. because other school subjects are equal or more important to the future success of the country.

E. because it will not work. Some people do not like science. It forces them to study, it will be to waste time and away from science (it will drive them away from science). 
F. Because not all students can understand science, although this would help them in their lives.

G. because not all students can understand science. Science is not really necessary for everyone.

$\mathrm{H}$. because it is not correct for others to decide whether a student should have (study) more science.

Among the sentences of question 20511, the only one to obtain a consensus of the judges and to be classified as "adequate" was item C, since it obtained a two-thirds majority of the judges (11 of 16). Already items A, B and D and were classified as "plausible", that is, if the participant punctuates one of these questions from 1 to 3 or from 7 to 9, the index will show a naive belief (-1), but score From 4 to 6 , the index will tend to +1 (adequate belief); Items E, F, G, and $\mathrm{H}$ were classified as "naive" because the phrase obtained the same two-thirds majority as a naive phrase, meaning that if the participant agrees to these items, his or her belief is considered naive .

The result obtained in question 20511 of QOCTS-PIEARCTS, applied to students and professors of exact sciences in CEFET-RJ, is represented in the table below.

\begin{tabular}{|llr|}
\hline 20511A_Plausible & Before university &,- 0900 \\
& Starting university &,- 0920 \\
& Finishing university &,- 1333 \\
& Teachers &,- 2159 \\
& Total &,- 1144 \\
& Before university &,- 2517 \\
& Starting university &,- 2184 \\
& Finishing university &,- 2667 \\
Concordance_20511C_Adequate & Teachers &,- 3977 \\
& Total &,- 2647 \\
& Before university &, 5336 \\
& Starting university &, 5057 \\
& Finishing university &, 4750 \\
& Teachers &, 7102 \\
& Total &, 5390
\end{tabular}


20511D_Plausible

20511E_Naive

Concordance_20511F_Naive

Concordance_20511G_Naive

Concordance_20511H_Naive
Before university

Starting university

Finishing university

Teachers

Total

Before university

Starting university

Finishing university

Teachers

Total

Before university

Starting university

Finishing university

Teachers

Total

Before university

Starting university

Finishing university

Teachers

Total

Before university

Starting university

Finishing university

Teachers

Total
$-, 1361$

$-, 0581$

$-, 2000$

$-, 2727$

$-, 1454$

,1655

,2857

2458

,5795

,2641

,2483

,2618

,3375

,5714

,3079

,5733

,5843

,6250

,7273

,6051

1711

,1977

,3208

,5682

,2559

As a social institution, the influence of education on the future of science and technology has reached consensus in one sentence of this question. For the success of science and technology, students should: (C) study more sciences, but in a different way from the accustomed one, that shows how science and technology affect their daily lives (Acevedo, 2008)

The consensus reached considers as naive belief the one that affirms that it is not necessary to study more sciences in the school, because (F) the students have great difficulty to understand sciences; $(G)$ not all students can understand science; And $(\mathrm{H})$ science is not really necessary for all people (Acevedo et al., 2008). 
Item A, as mentioned earlier, is a phrase considered by the judges as plausible and, from the data obtained and shown in the following chart, the belief of the institution's teachers is considered more naive than the students' beliefs, Shows that the teachers' score is the one closest to -1 .

Graph 1 - result of option A

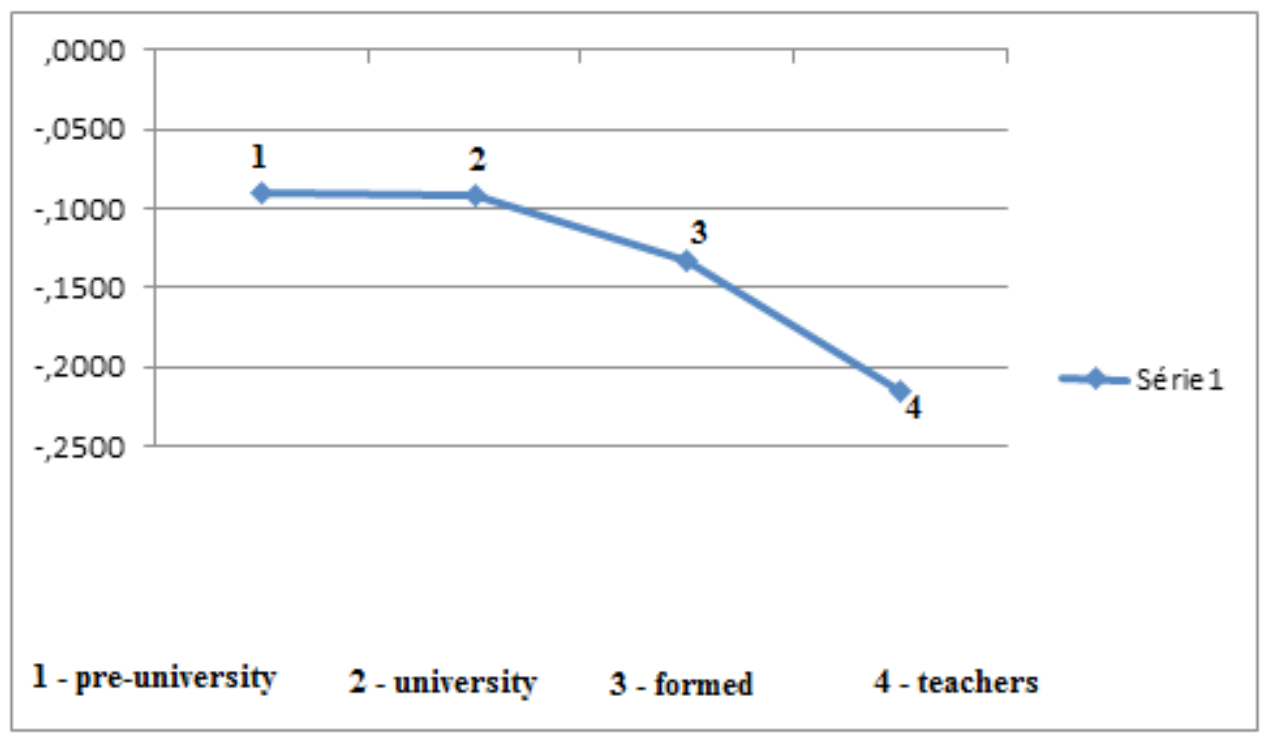

For this to occur teachers had a high degree of agreement with the statement (scored from 7 to 9), or a large high of disagreement from it (scored from 1 to 3 ), this made the score on average low, from -0.2159. In other words, it is naive to believe or to totally disbelieve that the importance of science education lies in keeping our country at the level of others.

Question B is a phrase considered plausible, which means that it is naive to state, or disagree, completely that the future depends on good scientists and technologists. 
Graph 2 - result of option B

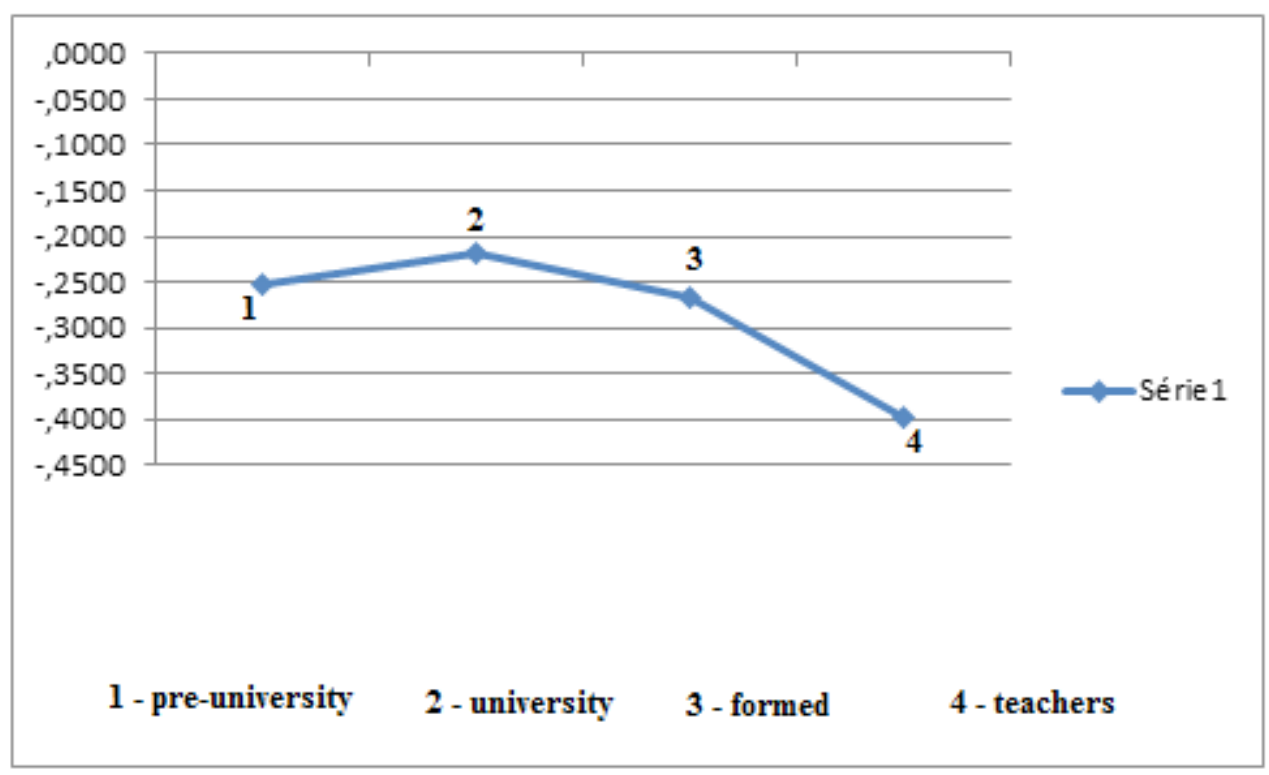

The result, shown in chart 2, shows that again the teachers 'beliefs are more naive than the students' beliefs. In addition, the same not only in the alert that not only the design of teachers, but also the design of students (and who knows future teachers) for the purpose of science education is still geared to the preparation of future scientists (propaedeutic purpose); But the purposes of scientific education have changed over time to a more recent one, which aims, in addition to the generation of scientific aptitudes, to scientific literacy, public understanding of science or popularization, and the extension of scientific and technological culture to all People (Acevedo et al., 2008).

The only sentence of question 20511 that obtained the consensus of the judges as adequate, stating that one must study a different form of sciences, a scientific education that shows how science and technology affect our daily life, was option $C$, where its result is Expressed in graph 3. 
Graph 3 - result of option C

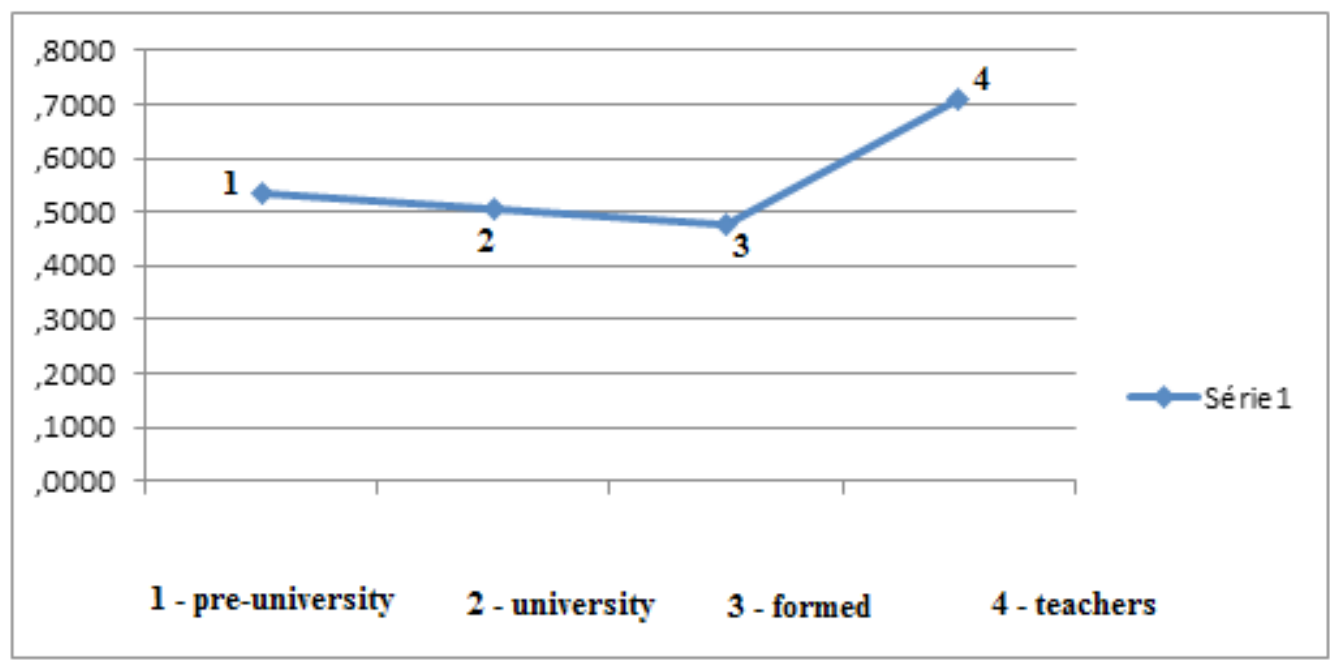

This phrase is in agreement with the National Curriculum Parameters for High School, where intercession occurs in the affirmation that it is necessary to rediscuss the science taught in the middle level, science that should enable students to better understand the world and a more adequate formation for Citizenship (PCNs, 1999).

Based on the results of item $C$ it can be noted that the belief of teachers and students tend to the most appropriate, especially the belief of teachers. This may be a good sign, as educators are aware that there must be changes in science education at the middle level. And considering that in this research there are teachers who teach only at the middle level, only at the upper and middle and higher level, we can say that there are professors who still defend the propedeutic purpose for teaching science, causing the average to be below of the most appropriate, 0.7102 .

The result of item $D$, which was considered by the judges as a plausible phrase, states that it is not necessary for students to study more sciences because other disciplines are equally or more important for the success of the country, is shown in graph 4. 
Graph 4 - result of option D

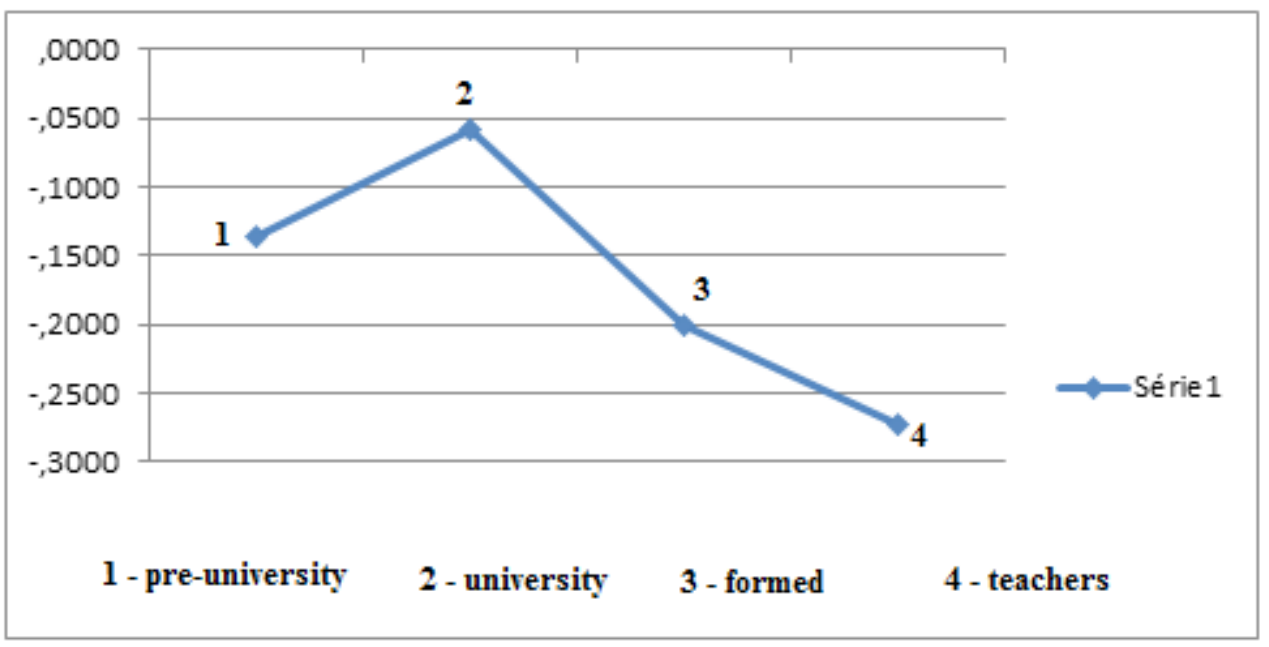

What we can perceive with this result is that the belief that teachers related to the area of exact have about this statement is more naive than that of their students. This means that teachers agree, or disagree, almost entirely with this statement they are likely to be in the exact area disagreeing almost entirely with this statement.

In science didactics, teachers' beliefs about $\mathrm{NdC}$ became a priority theme. Some investigations, cited by Acevedo at al $(2005$, p.3), were based on two hypotheses:

1 - Teachers' understanding of NdC has a certain relationship to that of their students and to the image they acquire from science.

2 - Teachers' beliefs about NdC have a significant influence on their way of teaching science and the decisions they make in class.

These hypotheses could explain the fact that students and teachers have similar beliefs in the above questions. Tedesco (2006) says that in order to change this framework, that is, to change the conception that teachers have about science - or the teaching of the nature of sciences - To the teaching sector, aimed at at least three fundamental variables: initial and continuing teacher training, working conditions and teaching careers. 
After all, teachers' beliefs on issues considered plausible (questions A, B and D) were all considered naïve by QOCTS-PIEARCTS, and obtained worse results than their students.

One of the top countries in international assessments of learning outcomes in science is Finland, where Tedesco (2006) states that the key to such success is the teaching factor.

In option $\mathrm{E}$, the conclusion of the judges was to consider it naive. Hence, if the participant fully agrees, his score tends to -1 ; If the participant disagrees completely with this phrase, his score tends to +1 .

Graph 5 shows that teachers disagree almost vehemently with this phrase, which is why their score approaches +1 , that is, they have a belief that is almost totally adequate in relation to the option $\mathrm{E}$.

Graph 5 - result of option E

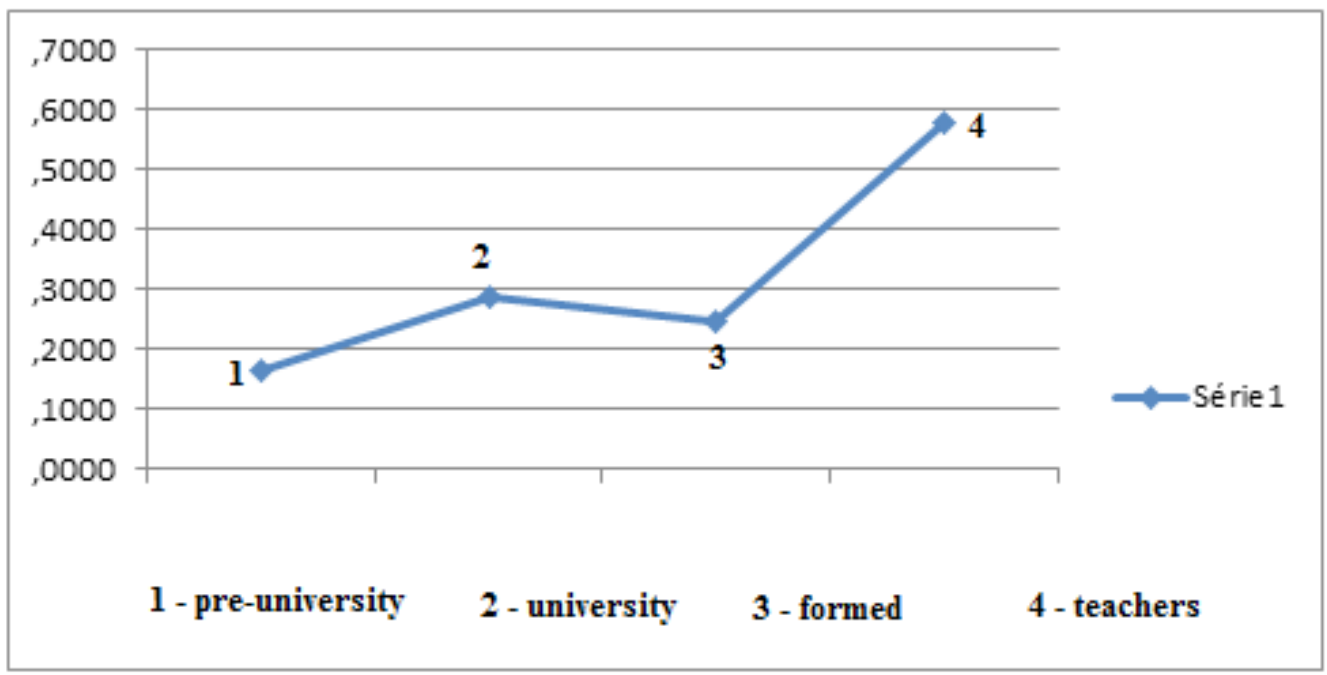

This question states that it is not necessary to teach more sciences because it will not work; That some people do not like science, and that forcing them to study will be a waste of time and will drive them away from science. 
We agree with the statement that some people really do not like science, but this should not be an argument for not teaching science. What needs to be done is a change in the basic science curriculum by making science seen as a language; Thus, being able to read the language in which nature is written is to be scientifically literate (Chassot, 2003).

In question $\mathrm{F}$, which was also considered a naive question, and therefore follows the same scoring criterion of the previous question, the result of the affirmation that one should not study more sciences because not all students can understand science, although That would help them in their lives is shown in graph 6.

Graph 6 - result of option $\mathrm{F}$

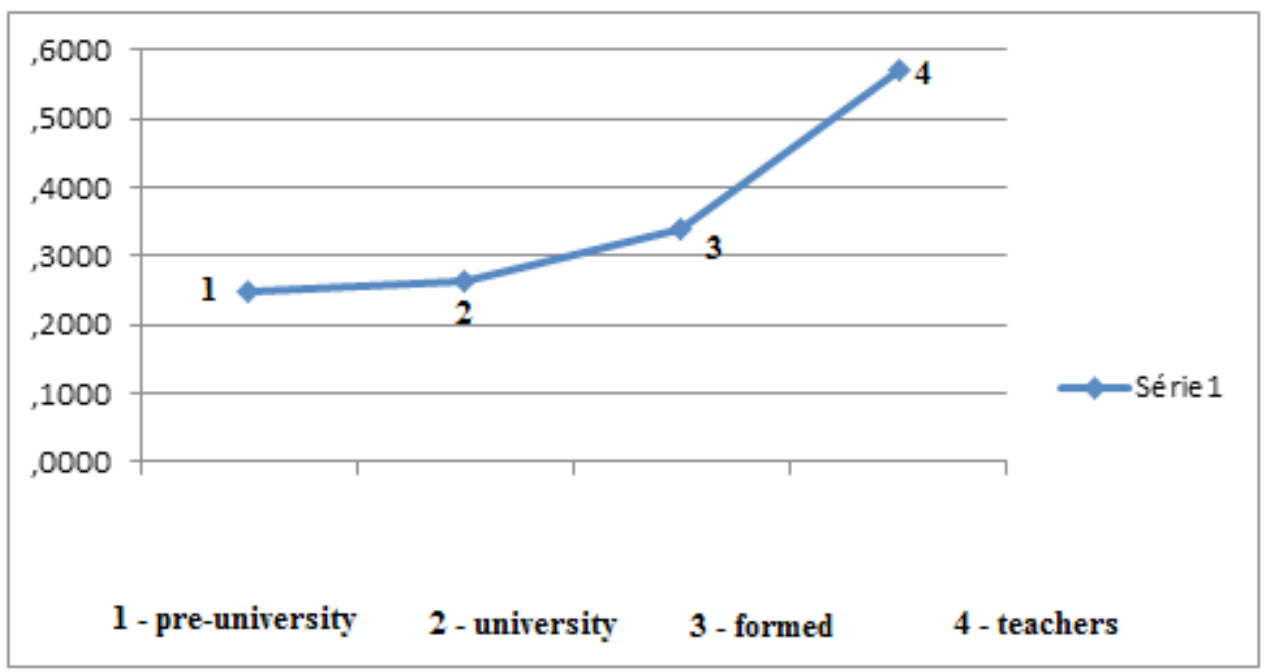

On average, teachers and students disagree with this assertion, and so their beliefs are considered plausible to appropriate.

All too often, the learning of science is reduced to students to an extremely frustrating task of assimilating mathematical techniques to solve the problems proposed in the tests. Therefore, finding ways in which to promote the correct understanding of fundamental concepts of science is the task of every teacher (Castilho and Ricci, 2006).

With regard to the result obtained in question $\mathrm{G}$, where it is stated that it is not neces- 
sary to teach more sciences for students, since not everyone can understand it, and that science is not necessary for all, we can see in figure 7 that the majority disagreed almost That totally of such affirmation.

This shows us that Cefet / RJ students and teachers are aware that we live in a scientific-technological world, and that science is necessary so that all citizens can at least participate in technoscientific decisions of social interest (Acevedo at al. , 2008).

Graph 7 - result of option G

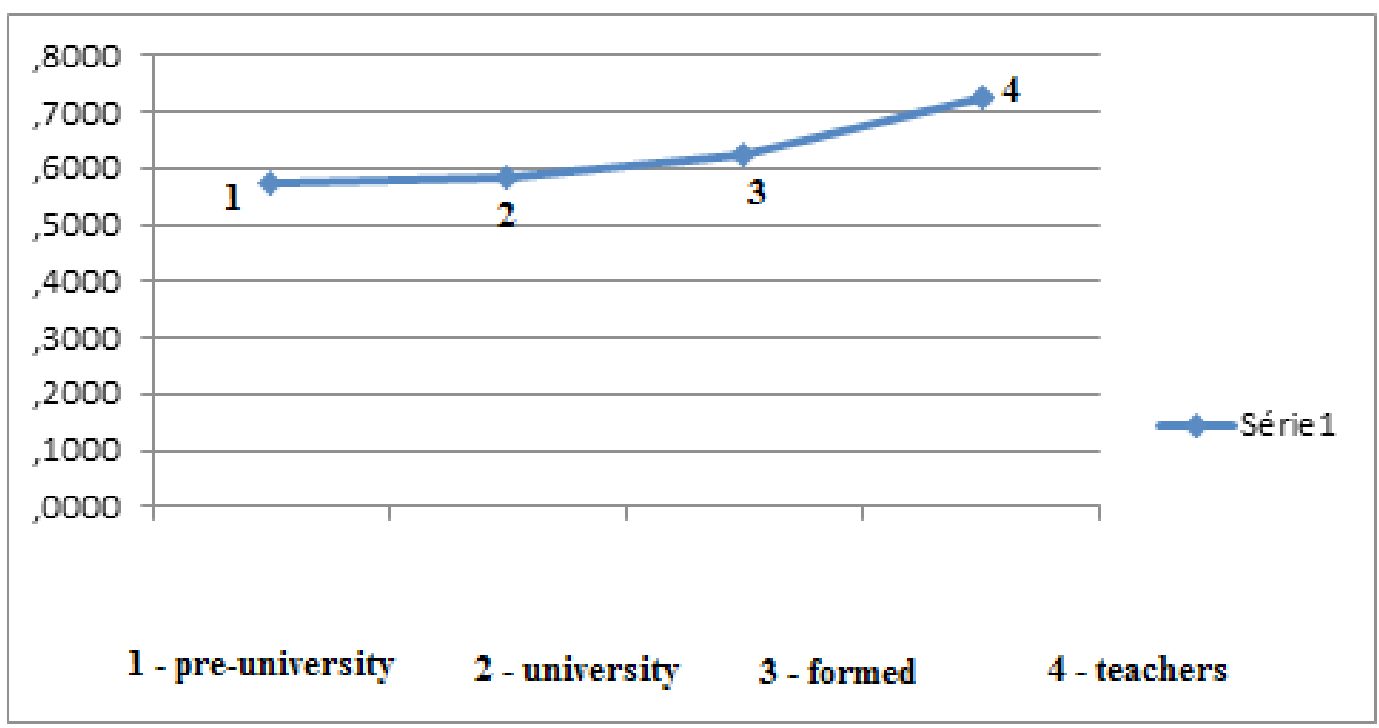

On this naive question, Bazzo (1998, p. 34 apud Bazzo, Pinheiro and Silverira, 2010) states: "the citizen deserves to learn to read and understand - much more than watertight concepts - science and technology, with its implications And consequences, so that they are able to participate in political and social decisions that will influence their future and that of their children."

In the last question, the result can be considered positive, because the phrase was considered naive by the judges, and the teachers obtained the best result. As for 
the result of the students of the 3rd year of high school, their beliefs can be classified as plausible.

$$
\text { Gráfico } 8 \text { - resultado da opção H }
$$

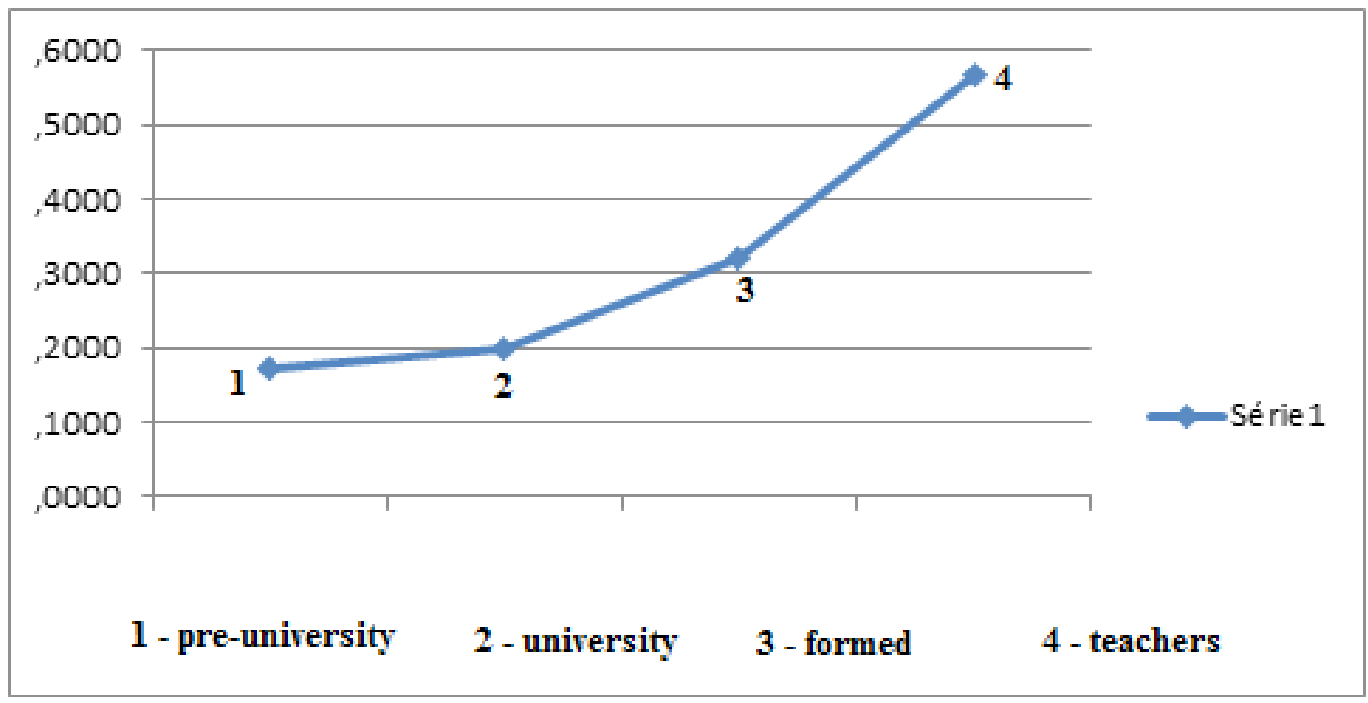

The argument that the phrase is used for students not to study more sciences is: because it is not correct that others decide if a student should study more science. This argument leads us to a question: who should, or who would be the best, for this decision?

On the basis of the education to be provided in a democratic society, there is a need for the participation and involvement of as many citizens as possible in decisionmaking about the choices made by contemporary science, and this will only be possible through an understanding of what Is science and how it is produced (Osborne, 2000 apud Galvão and Reis, 2005). And the teacher would be the bridge between scientific circles and educational institutions.

According to Day (1999), professional teacher development is a complex process (based on a dialectic between action and reflection), through which he, individually or with others, reformulates his personal orientations regarding the purposes of 
Teaching and critically developing the knowledge, techniques and intelligence (cognitive and affective) indispensable to the practice of quality practice in the school context. Such professional development entails in the preparation of their students so that they can have a critical analysis of controversial socio-scientific questions.

\section{CONCLUSION}

Given the results presented, we can verify that, at times, there is a divergence between the beliefs that the judges delegated as ideas and the beliefs of the education professionals. Graph 9 shows a comparison with the statement of the results of the beliefs of the teachers of exact and human about the question 20511.

\section{Graph 9 - overall result}

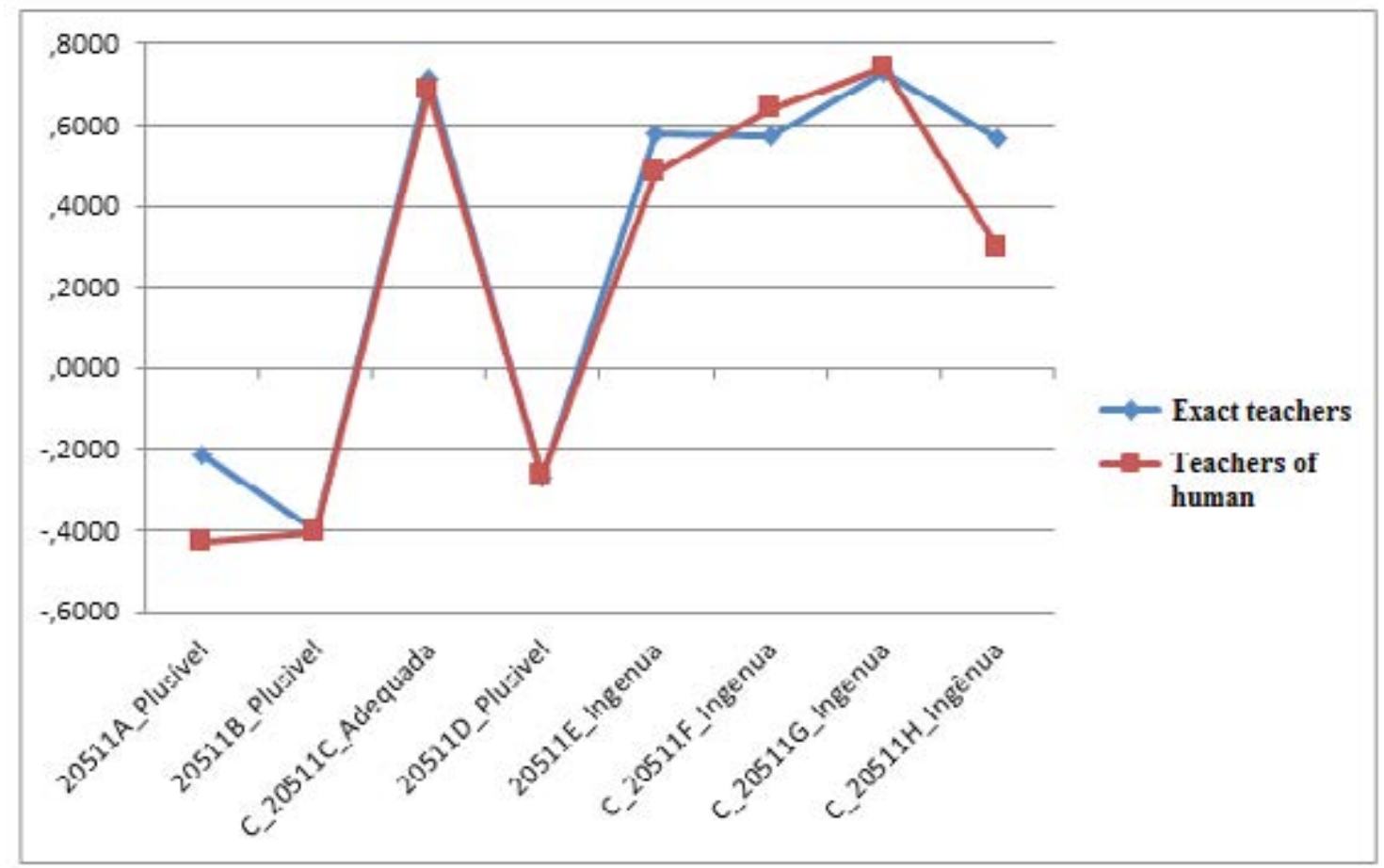


In general, the scoring of each option described above should be as close as possible to +1 , so that teachers' beliefs and approaches are classified as appropriate. However, what can be perceived is that the conception of teachers about the ideal scientific education, in some points, is far from adequate.

In most items, the exact teachers' scores are identical to those of human teachers, this may mean that, regardless of the subject they teach, teachers share a similar opinion, but in some questions it is observed that such opinions are considered naive.

These issues where the beliefs of teachers were classified as naive are assertions that maximize the importance of science and technology for the future of society. It is likely that the exact teachers scored between 7 and 9, agreeing with the statements, and the teachers of humans between 1 and 3, disagreeing with these statements. Thus, the scores tended to - 1 , because there were questions that did not obtain the approval of the judges and for that reason they were considered plausible.

But the stakes for a science education aimed at forming a citizenship, rather than a preparation for future scientists, generate resistance in several teachers, who legitimately argue that society needs scientists and technologists who have to be trained and be (Vilches, Solbes and Gil-Pérez, 2004 apud Gil-Pérez, Praia and Vilches, 2007), thus justifying the naive belief of the teachers in question $C$.

In this sense, for an improvement in scientific education, there must be a change in the conception that teachers have and transmit from the nature of science, that is, if we want to change what teachers and students do in science classes, It is necessary to modify the epistemology of the teachers beforehand (Bell and Pearson, 1992 apud Gil-Pérez, Praia and Vilches, 2007).

Acevedo Díaz (2010) argues that research conducted over the past decade has shown clearly that science teachers do not generally have a good understanding of the nature of science. Thus, the need to pay more attention to the nature of science in science teacher training courses is evident.

Another obstacle to a change in science teaching in secondary education, apart from the lack of preparation of teachers, is the lack of specific didactic material for the 
scientific education that one wants to implement. The great majority of the didactic materials are directed to a preparatory training, having as an "appendix" some contextualized contents, which most of the time goes unnoticed.

As a solution to the problem in science teaching, Cerezo (2002 apud Bazzo Silveira and Pinheiro, 2007) says that Spain introduced CTS as an elective course in all undergraduate courses and, in high school, compulsory as a transversal complement of science disciplines. This caused several high school and higher education teachers to seek improvement, thus leaving the "comfort zone".

Regarding changes in teachers' conceptions, we can cite the analogy made by Gordillo and Galbarete (2002 apud Tedesco, 2006 p.29) between science teaching and art teaching:

Artistic education does not pretend that all are musicians, painters or writers, but are able to enjoy art. Therefore, the scientific and technological education of citizens should not pretend that all citizens are able to build a bridge, but rather allow everyone to participate in decisions about whether the bridge should be built in a certain place and on what functions it should accomplish.

We believe that the insertion of the teaching of the nature of science (with a CTS approach) in Secondary Education can promote a teaching-learning that provides the student with a fundamental scientific and technological literacy for the formation of critical citizens who, in the future, will be able to participate in the Decisions.

\section{REFERENCE}

ACEVEDO DÍAZ, J. A. (2010); Formación del profesorado de ciencias y ensenanza de la naturaleza da la ciencia. Revista Eureka sobre Enseñanza y Divulgación de las Ciencias, 2010, 7(3), pp. 653-660.

ACEVEDO-DÍAZ, J. A.; ACEVEDO-ROMERO, P.; MANASSERO-MAS, M. A.; VÁZQUEZ-ALONSO, A.; Consenso sobre a natureza da ciência: a ciência e a tecnologia na sociedade. Química Nova na Escola, no 27, fevereiro 2008. Acesso em 10 de jul., 2013, http:// 
qnesc.sbq.org.br/online/qnesc27/07-ibero-6.pdf

ACEVEdo, J. A.; ACEVEdO, P.; MANASSERO, M. A.; PAIXÃO, M. F.; VÁZQUEZ, A. (2005); Mitos das didáticas das ciências acerca dos motivos para incluir a natureza da ciência no ensino das ciências. Ciência e Educação. V. 11, n. 1, p. 1-15. Acesso em 25 de jul., 2013, http://www.scielo.br/scielo.php?script=sci_arttext\&pid=\$1516-73132005000100001

BAZZO, W. A.; PINHEIRO, N. A. M.; SILVEIRA, R. M. C. F. (2007); Ciência, tecnologia e sociedade: a relevância do enfoque CTS para o contexto do ensino médio. Ciência e Educação, v. 13, n. 1, p. 71-84, 2007. Acesso em 25 de jul., 2013, http://www.scielo.br/ $\mathrm{pdf} / \mathrm{ciedu} / \mathrm{v} 13 \mathrm{n} 1 / \mathrm{v} 13 \mathrm{n} 1 \mathrm{a} 05 . \mathrm{pdf}$

CHASSOT, A. (2003); Alfabetização científica: uma abordagem para a inclusão social. Revista Brasileira de Educação. № 22.

GALVÃO, C.; REIS, P. (2005); Controvérsias sócio-científicas e prática pedagógica de jovens professores. Investigações em Ensino de Ciências - V10(2), pp. 131-160, 2005. Acesso em 25 de Jul., 2013, http://www.if.ufrgs.br/ienci/artigos/Artigo_ID126/v10_ n2_a2005.pdf

GIL-PÉREZ, D.; PRAIA, J.; VILCHES, A. (2007); O papel da natureza da ciência a educação para a cidadania. Ciência e Educação, v. 13, n. 2, p. 141-156. Acesso em 26 de Jul., 2013. http://www.redalyc.org/articulo.oa?id=251019508001 
MANASSERO-MAS, M. A.; TALAVERA, M.; VÁZQUEZ-ALONSO, A.; Actitudes y creencias sobre naturaleza de la ciencia y la tecnología em uma muestra representativa de jóvenes estudiantes. Revista Electrónica de Enseñanza de las Ciencias Vol. 9, № 2, 333352 (2010). Acesso em 21 Ago., 2013. http://www.oei.es/cienciayuniversidad/spip. php?article1605

TEDESCO, J. C. (2006); Prioridade ao ensino de ciências: uma decisão política. Organização dos Estados Ibero-Americanos. 